\title{
Problems of selected types of mortgage loan risks in Poland
}

\author{
Antoni Magdoń \\ University of Rzeszów \\ Faculty of Economics, Rzeszów, Poland
}

\section{Key words}

Risk, bank, mortgage loan, variable and fixed interest rate

\begin{abstract}
The main purpose of the study is to present the characteristics of risk associated with the lending policies of banks, with particular focus on mortgage loans in Poland. Risk is concomitant with any economic activity, regardless of the sector in which it is conducted. It is also an unavoidable element in the banking sector and its lending activities, including granting mortgage loans. The study contain an analysis of the current situation of the mortgage loan sector, which is largely based on variable interest rates. It is one of the main potential sources of system risk in the banking sector in Poland. It also demonstrates the opportunities for a wider introduction of fixed-rate mortgage loans onto the Polish market. Fixed-rate mortgage loans have benefits for both the client and the bank. Increasing the number of fixed-rate loans would strengthen the Polish banking sector while also providing greater stability and security to borrowers.
\end{abstract}

Corresponding author: Antoni Magdon

Email addresses for corresponding author: antoni.magdon@gmail.com

First submission received: $27^{\text {th }}$ August 2017

Revised submission received: $27^{\text {th }}$ January 2018

Accepted: $15^{\text {th }}$ February 2018

\section{Introduction}

Economic growth in Poland is significant. After leaving communism, the GDP per capita growth in Poland was fast and stable and remained around $4 \%$ per year. In less than 15 years Poland has moved from medium to high status. The economy expanded rapidly thanks to investments and innovations. After the transition from communism to capitalism, Poland got the institutions right, namely the rule of law, property rights, democratic accountability, and basic market institutions. It then used EU accession and membership to strengthen them. The right macroeconomic policies ensured stability and resilience. Poland was the only European country to have experienced a positive growth in 2008 - the year of the global crisis-and completely avoid a banking sector crisis due to Poland's effective restructuring, regulating and supervising of the financial sector (Lessons from Poland).

The Financial Stability Report published by the NBP in February 2016 underlines the continuing stability of the sector towards end-2015. The report shows about $98 \%$ of Polish banks with a capitaladequacy ratio above the $12 \%$ minimum, continued solid growth in loans and zloty deposits, and a gradual downfall in the incidence of bad loans. In 2016 the fluctuation of the Polish currency will have underlined the importance of the mortgage-conversion plan, because in April 2016 more than 20\% of Polish household loans, valued at about US\$ 36 bln, were still denominated in Swiss francs (Poland: Banking sector risk, 2016).

In 2015, Polish banks overall equal fairly well with the $-10 \%$ depreciation of the PLN against the $\mathrm{CHF}$ in the wake of the removal of the EUR: CHF exchange rate floor by the Swiss National Bank in January, even though CHF-denominated loans of household and NFCs (non-financial corporations) accounted for about $16.4 \%$ of total loans or $7 \%$ of GDP (Poland, Country Report).

\section{Credit risk and lending policy}

Several kinds of risk are present in banking activities. These include liquidity risk, credit risk, interest rate risk and principal risk (Kulpa, 2015). These kinds of risk are included in the internal factors influencing the financial results achieved by banks (Magdon, 2014).

Credit risk is the oldest kind of risk existing on the financial markets. Traditionally, banks performed credit risk assessments using highly subjective methods, and on the basis of unclear criteria.

www.jbrmr.com A Journal of the Academy of Business and Retail Management (ABRM) 
They often sought to maintain good relations with their clients at the cost of the profitability of individual loans, without paying attention to how those transactions influenced the quality of their loan portfolio (Dylewski, 2010). This approach had far-reaching financial consequences, such as the Asian crisis of the 1990s and the global financial crisis of 2007-2008. Many financial institutions did not survive on the market, or found themselves in a critical situation requiring external support (Magdon, 2015). The reasons for incorrectly assessing credit risk varied. Usually, banks fell prey to their own ignorance of the practical use of scientific achievements in developing their lending policy based on economic forecasts (Gwizdała, 2011). At the same time, there has been considerable difficulty in exchanging information and joint decision-making by central banks, supervisory authorities and finance ministry (Report. The High-level). An economic downturn or upturn has a practical dimension, and influences the requirements or rules for granting loans (Gwizdała, 2011).

Credit risk in banking activities is defined as the occurrence of a situation in which the borrower fails to repay the loan in accordance with the agreement, or a party to the transaction fails to comply with the obligation to repay the loan. For most banks, credit risk is the most significant source of risk.

The level of credit risk is the sum of many factors. These include:

- lending policy,

- lending process quality,

- $\quad$ innovations on the bank loan market (Gwizdała, 2011).

Banks enjoy a relatively high degree of freedom in conducting their lending activities. This freedom might be seen as dangerous, and leading to an increase in credit risk. With regard to the above, in the lending activities of a commercial bank it is important to establish a general policy aimed at minimising risk effectively. Every bank prepares its main objectives, a strategy taking into account the external circumstances, and defines the tool for implementing its lending policy. The assumptions of the lending policy should be laid down in a detailed and precise manner. The content of the policy should facilitate the control of risk increase and strictly define the criteria of acceptable credit risk (Gwizdała, 2011).

The lending policy definition can be expressed in a variety of ways. I will quote two definitions from the literature. "Lending policy - the guidelines which define, taking into account the existing circumstances, the specific details of lending activities, which can vary in different banks and across various periods" (Głuchowski, 1994). A lending policy might also be defined as "a set of rules, guidelines and recommendations regarding all issues connected with lending activities, which is the basic instrument for the implementation of a selected strategy of managing credit risk" (Turlej, 1994).

For professional credit risk management, it is necessary to employ four elements, i.e.

- risk measurement and the appraisal of the market value of individual bank loans,

- the appraisal and measurement of the portfolio's credit risk,

- the development of reliable databases providing input for models defining credit risk,

- the growth of the market for credit derivatives which are essential for risk transfer (Altman, Caonette, Narayaanan, 1997).

All aspects of lending policy are interconnected, and depend on a number of internal and external factors. The dynamics of the lending activities of each bank is, on the one hand, defined by external factors, which shape the demand for bank loans in the economy, such as the monetary policy of the central bank, the investment activity of economic entities, the development of the financial market segments, and the level of competitiveness of a given bank in relation to other financial entities. On the other hand, there are a number of internal factors which are shaped by the bank itself. These factors include the correlations between increased lending activity and pricing policy, the structure of deposits forming the source of lending activities and the amount of equity capital, the amount of assets at risk, the effectiveness of the bank's organisational structures, and the quality of service provided to borrowers. An analysis of external and internal factors which affect the extent of credit activities (the number and volume of loans granted) defines the basic area of a bank's lending policy for shaping a bank's balance structure and long-term liquidity (Gwizdała, 2011).

Another area of lending policy is shaping the structure of the loan portfolio. The bank makes decisions with regard to the territorial and sectoral diversification of loans, indicating the internal loan 
limits for specific segments and companies, and their technical structure. A loan's technical structure consists of the conditions for granting loans, the purpose of the loans, the repayment dates, fees and commissions, and interest rates (Żółtowski, 2007).

The last aspect of a bank's lending policy is composed of the decision-making criteria used to grant or refuse a loan, which result from:

- the procedures use to assess creditworthiness,

- the relationship between the creditworthiness assessment and the bank's lending policy,

- a combination of all the elements of lending policy (Gwizdała, 2011).

\section{The types of banking strategies}

The development of banks' operations and their financial standing are connected with the general economic situation, and the state of the entities which have taken out the bank's loans, especially companies, which are usually the major borrowers, becoming the bank's most important partners as a consequence. An economic slowdown usually causes the demand for loans and banking services to decline, resulting in a loss of income and simultaneous attempts to find an appropriate way to protect one's funds and recover contentious receivables. An economic upturn, on the other hand, prompts an intensive search for the sources of financing of numerous businesses, which in consequence leads to increased demand for loans and banking services, the development of the bank's activities, and an increase in income (Kosiński, 1993).

Taking into account the said interrelations, the bank prepares a development plan, specifying the acceptable fluctuations in income from lending activities, adjusting for credit risk. This involves the selection of one of the following strategies:

- a conservative strategy,

- a controlled risk increase strategy,

- an offensive strategy.

A bank which has adopted a conservative strategy does not achieve high profits during an economic upturn, but neither does it incur high losses during a downturn. Income fluctuations will be subject to slight changes throughout the whole business cycle. Choosing this strategy means that it is the bank's fundamental priority to safeguard the high quality of its loan portfolio. Implementing this strategy requires a high degree of internal discipline from the bank, in terms of granting loans, and its immunity to market sentiments. A controlled risk increase strategy means that income fluctuations throughout the whole business cycle are greater. During an upturn, the bank will gain more than when following a conservative strategy, but during a downturn it will lose more than its competitors using a conservative strategy. A rapid increase in income is the priority here. In the overall business cycle, a bank using this strategy records higher profits than banks which have adopted a conservative approach.

In an offensive strategy, the rapid development of the bank and the dynamic increase in its size, significance and market share become the priorities. As a result, the management of the bank must accept high fluctuations in the bank's income. This strategy is very difficult to implement, as it requires placing emphasis on the control of strategic assumptions, and setting up a number of "warning signals" to quickly identify the changes going on in the bank and its environment. An uncontrolled strategy which is not stopped at the right moment could lead to numerous serious consequences, resulting in lower profitability (Gwizdała, 2011).

Observing such practice, commercial banks adopt activities aimed at secure development and a good quality loan portfolio, paired with higher credit exposure. To achieve the said objectives, it is very important to prepare the adequate procedures and methods to reduce the risk of granting loans which will become "bad" debts. Banks as lending institutions must, due to an increase in credit risk, continually improve the organisation system for the lending process, adjusting its procedures to the changing circumstances in which they operate (Gwizdała, 2011).

\section{Mortgage loan risk}

In recent years, as a result of the rapid development of the financial system, globalisation processes, and an increase in society's wealth, there has been an increase in the significance of one banking product - namely the mortgage loan. Mortgage loans are considered the basic source of financing 
for residential and commercial construction in Poland, and they also form an indicator of the adoption of the market economy. The entities responsible for developing this product are the banks, whose operations including engaging in deposit and lending functions (Pastuszka, 2015).

Mortgage loans are the fundamental component of retail banking in Poland. Their enormous significance is confirmed by statistical data (as presented in the chart below), which demonstrate that mortgage loans represent over $80 \%$ of the entire retail banking market in Poland.

\section{Chart 1. Retail banking loans by type in Poland in 2014}

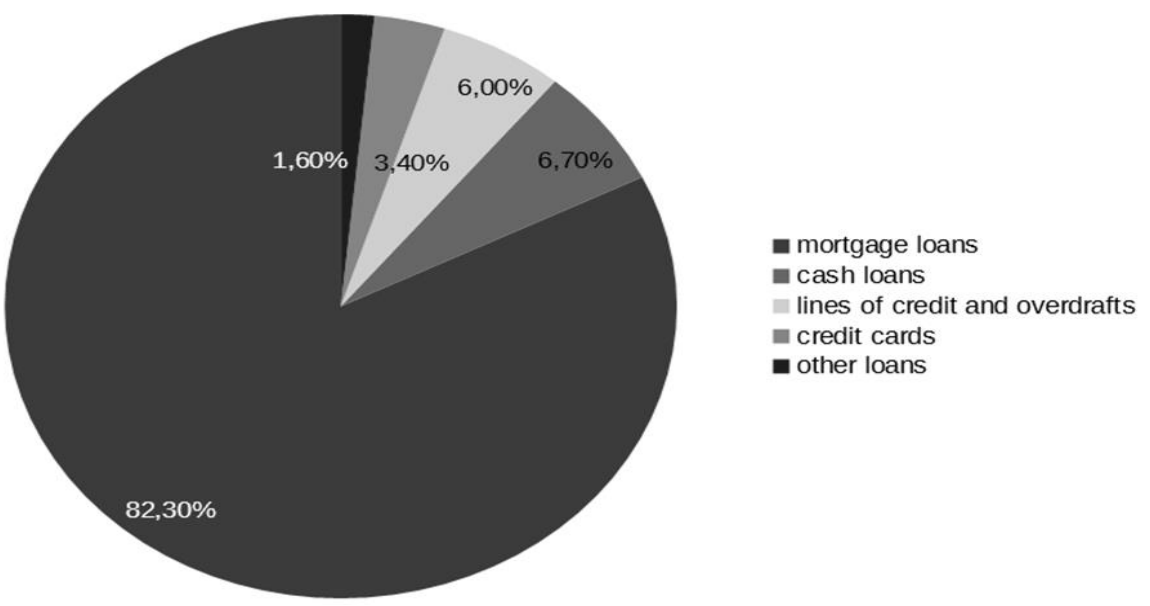

Source: Pastuszka, (2015), accessed on 17.07.2017

Credit risk is the basic type of risk associated with banking, not only mortgage banking. The characteristic feature of credit risk in mortgage banking is the long-term financing of mortgage loans, which means that there are difficulties in predicting the amount of the borrower's income in the future (Pastuszka, 2015).

Another type of risk involved in lending activities is interest rate risk. The interest rate is the key element in the operation of the entire financial system. It affects both loans and deposits. Its changes determine the profitability of a given enterprise or investment and can cause its failure. According to the Basel Committee on Banking Supervision, interest-rate risk is the risk of the adverse influence of interestrate changes on a bank's financial standing (Gąsowska, 2000). This means that the bank can incur a loss due to the resources committed to a given project under specific conditions, as with time it might be found unprofitable from the bank's point of view.

If we look at the market for mortgage loans, it becomes apparent that the interest rate is closely tied in with the real property market. Obviously, mortgage loans involve much higher amounts than consumer loans, which is why the demand for them depends on their interest rate, which consists of a fixed bank margin and a variable interest rate. The interest rate is the "price of money" used by the banks to grant loans to each other on the interbank market. In the case of loans denominated in PLN, the interest rate is WIBOR, and for the basic foreign currencies - LIBOR or EUROLIBOR. The interest rate determines the cost of a mortgage loan, which is why it is crucial for potential borrowers and investors. When the interest rate rises, mortgage loan servicing costs increase, which also leads to reducing the demand for real property (Pastuszka, 2015).

Interest rate risk is connected with the bank's assets and liabilities. To reduce it, banks must run a prudent lending policy, which excludes the situation in which the costs incurred from deposit--related activities are higher than the profits achieved from lending activities (Principles for the Management and Supervision of Interest Rate Risk 2001).

\section{A variable interest rate and its significance for the polish mortgage loan market}

According to one of the presented opinions of the Financial Stability Committee (the Committee involves representatives of four main institutions in Poland's financial-security network, i.e. the National Bank of Poland, the Polish Financial Supervision Authority, the Ministry of Finance and the Bank Guarantee Fund) of 2015, one of the main potential sources of system risk in the banking sector is a very 
large portfolio of variable-rate mortgage loans in PLN, taking into account the historically low interest rate and the banks' credit policies. Currently, granting mortgage loans for long periods on the basis of the 3-month or 6-month WIBOR rate is a serious challenge for macro-prudential analysis (Ramotowski, 2017).

Also, the Financial Supervision Committee in the "Report on the situation of banks" for 2015 defined the risks connected with the current situation. Announcing the draft amendment to Recommendation S, the Polish Financial Supervision Authority (KNF) stated that with mortgage loans currently granted for an average of 25 years and with low interest rates, banks must take into account the risk that nearly the entire loan volume would be repaid during a time of higher interest rates.

A series of interest rate reductions began in 2012, from the level of 4.75 percent for the reference rate. In 2013 there were six reductions, and the current historically low reference rate, 1.5 percent, has been in force since March 2015. In a span of nearly two years since this rate was set, the commercial banks have granted nearly PLN 70 billion in mortgage loans (as at December 2015). For a large group of borrowers, low interest rates meant higher credit scores. PLN 70 billion represents about $18 \%$ of all mortgage loans in the portfolios of banks. We do not know what part of these were granted involving underestimated maintenance costs or with excessively low buffers to make up for the risk of interest rate increases. We know that this was the case from KNF's studies, which has since 2014 issued several warnings to banks to avoid such policies.

The problem is not only that the largest part of the repayment of loans granted under the current conditions of low interest rates will be in a situation of a significantly higher price of money, but the high interest rates increasing the loan instalments might be accompanied by increasing loan servicing costs. Such a situation could mean that when we enter the stage of interest rate increases, this will automatically trigger a series of changes reducing the quality of mortgage loans, especially those taken out in recent years. Each successive interest rate increase will cause the credit risk to go up. In the case of interest rate increases, the Polish Financial Supervision Authority is planning to introduce limits for granting loans to clients with the highest risk, i.e. having a high debt-to-income ratio (Ramotowski, 2017).

At the same time, financial supervision officials, financial market regulators and bank representatives are discussing how to create favourable conditions for introducing fixed-rate mortgage loans, which would mean a fixed monthly loan instalment for a previously specified period.

The proportion of variable-rate mortgage loans in the entire pool of mortgage loans in Poland is nearly 100 percent.

Chart 2. The proportion of fixed-rate and variable-rate loans in the balance sheets of banks - Over 5 years $\square$ from 1 to 5 years $\backsim$ up to 1 year

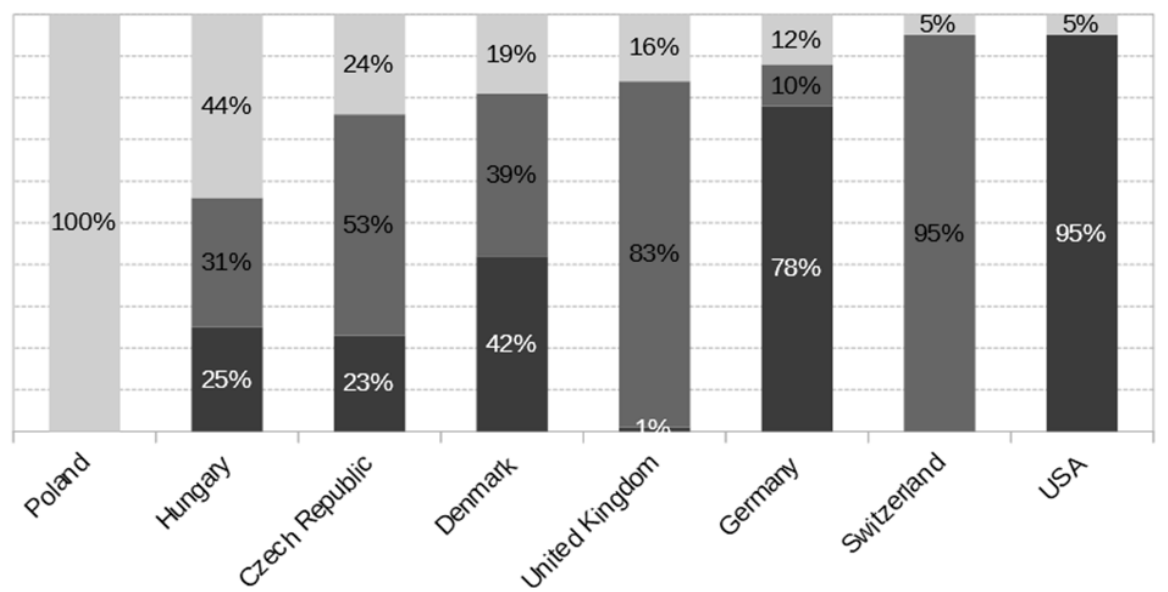

Source: Ramotowski, (2017), accessed on: 15.07.2017

Both in Europe and in the US, fixed-rate financing is predominant in mortgage loans: in Germany $78 \%$ of loans are granted with a fixed interest rate for a minimum of five years, and in the US as many as 95\%. In the European Union, variable-rate loans represent 43 percent of banks' mortgage loan volume. In granting a fixed-rate loan, banks do not fix the rate for the entire loan term, especially for borrowers with a lower income, who take out loans for 20-30 years. Usually the rate is fixed for a period of 5 to 10 years. 
This period is followed by a refix, which involves determining a new interest rate for the next several years.

Fixed-rate loans protect the borrower from interest rate changes in the period when the rate is fixed. The longer the period, the higher the interest rate risk borne by the bank. However, banks can allocate this risk. It is for this reason that fixed-rate loans are more advantageous, as the bank can hedge itself against interest rate risk, while the borrower has no such options (Ramotowski, 2017). When the fixed-rate term expires, the interest rate is re-fixed for another term. The increase can be steep. In such a case, a variable-rate loan appears more advantageous for the borrower, as the instalments increase gradually. In the case of a fixed-rate loan, the borrower can take advantage of a competitive fixed-rate or variable-rate loan. The borrower can also insure the fixed rate for the entire repayment period.

However, under the current conditions in Poland, a fixed rate loan is bound to be more expensive than a variable-rate loan, and the instalments will be higher. For this reason, the supply of fixed-rate loans is meeting with very low demand. Borrowers benefit from a fixed rate when interest rates rise, but lose when they fall. In this case they would be more willing to repay the loan earlier or convert it in a different bank to a variable-rate loan. This, in turn, would generate an additional cost of maintaining securities or closing positions if the loan is repaid. It is here that the banks' greatest fear lies, and regulating the valuation of this element is the subject of discussion.

Clients have not yet realised that the variable-rate risk is borne by them alone, while in fixed-rate loans the risk is divided between the client and the bank. The longer the periods between refixes, the lower the consumer's risk, and the higher that of the bank. When granting a fixed-rate loan, the bank must hedge the risk, which is why fixed-rate loans, especially in a time of low interest rates, are more expensive than variable-rate loans and the instalments are higher (Ramotowski, 2017).

\section{The opportunity for the fixed rate}

The high demand for variable-rate loans has probably resulted from two phenomena. The first is the hyperinflation which occurred at the beginning of the transformations in the last years of the 20th Century, and the almost-twenty-year period of falling inflation which followed. The second reason is the expectation to pay as small instalments as possible (and not, e.g., to obtain a loan with the lowest possible total cost) (Ramotowski, 2017). Furthermore, social factors also play a huge role - Poles want to improve their social status, and having your own flat or house is an indicator of such an improvement. This is facilitated by Poland's improving economic status, falling unemployment rate, rising earnings, and very high supply of flats on the market. The price of the mortgage loan determined according to a fixed interest rate could be out of reach for the average Pole, which would make purchasing a flat less possible for them. The above factors determine consumer choices.

The current period of the lowest interest rates in our history, and, even more so, the increasingly realistic prospects that they will rise, is creating opportunities to change the interest rate structure of mortgage loans. This is important, as the role of the banking sector is to skilfully manage credit risk so that the products provided are secure and contribute to making Polish people wealthier in the long run.

The first condition for introducing fixed-rate loans is the financing of mortgage loans by issuing covered bonds. Since early 2016 the Act on Covered Bonds has been in force in this respect, thanks to which some Polish banks have accelerated the issuing of these instruments to refinance their loans. The second crucial condition is to create a liquid market for instruments hedging banks against interest rate changes. However, the most important condition is the client's awareness of the risk incurred by taking out a variable-rate loan. This risk should be communicated to clients by the banks. The Act, in its draft adopted by the Government in late 2015, implements the EU Mortgage Credit Directive (MCD) in Poland. Its aim is to improve the protection of consumers signing mortgage-loan agreements and bridging the information gap between clients and banks.

How long the periods between interest rate refixes should be is still undecided. Meanwhile, the greatest risk, and also potential loss, for banks, is represented by the repayment of fixed-rate loans before the term, and particularly before the refix date. This scenario would be disadvantageous for banks, as they would have to bear the costs of closing hedging positions or maintaining them, even though the loan has been repaid. 


\section{Summary}

Fixed-rate mortgage loans have benefits for both the client and the bank. Increasing the number of fixed-rate loans would strengthen the Polish banking sector while also providing greater stability and security to borrowers. However, a few years will probably pass before fixed-rate mortgage loans become popular on the Polish market, as even the representatives of the banking sector are not convinced of the need to introduce this product into their package. The November 2016 issue of Monitor Bankowy (The Banking Monitor) presents the results of a survey which show that only 39\% of respondents were in favour of a fixed interest rate, and as many as $58 \%$ of respondents were opposed to it, claiming that the risks involved were too high for banks to be able to offer attractive interest rates for such loans (Pilcicka 2016).

\section{References}

Altman E., Caonette J., Narayaanan P., Credit Risk Measurement and Management, "Journal of Finance" 1997, no. 31.

Dylewski M. ed., Ryzyko w finansach i bankowości w warunkach kryzysu gospodarczego (Risk in Finance and Banking in an Economic Crisis), Wydawnictwo Wyższej Szkoły Bankowej w Poznaniu, Zeszyty Naukowe, No. 29, Poznań 2010.

Gąsowska A., Bankowość hipoteczna (Mortgage Banking), Poltext, Warsaw 2000.

Głuchowski J. ed., Leksykon bankowy (Banking Lexicon), Edytor S.A., Warsaw 1994.

Gwizdała J.,Ryzyko kredytowe w działalności banku komercyjnego (Credit Risk in the Activities of a Commercial Bank), Wydawnictwo Uniwersytetu, Gdańskiego, Gdańsk 2011.

Juszczyk J., Kredyt bankowy jako źródło finansowania (Bank Loans as a Source Financing), Buchalter, 1997.

Kosiński B., Ekonomika banku komercyjnego (The Economics of a Commercial Bank), Poltext, Warszawa 1993.

Kulpa W., Operational Risk Management in a Bank, University of Rzeszów Publishing Office, Rzeszów 2015.

Magdoń A., Adekwatność kapitałowa banku komercyjnego (The Capital Adequacy of a Commercial Bank). Universitati serviens. Księga pamiątkowa ku czci Księdza Profesora Stanisława Wilka SDB, ed. Rev. Jan Walkusz, Marzena Krupa, Wydawnictwo KUL, Lublin 2014.

Magdoń A., Wpływ regulacji Bazylea III na sektor banków spółdzielczych w Polsce (The Impact of the Third Basel Accord on the Cooperative Banking Sector in Poland), Roczniki Ekonomii i Zarządzania, Vol. 7 (43) - 2015.

Pastuszka A. , Zeszyty Naukowe Politechniki Częstochowskiej, Zarządzanie No. 18,2015.

Pilcicka A., 2016, Kredyty hipoteczne o stałej stopie procentowej w polskich realiach (Fixed-rate Mortgage Loans in the Polish reality), [Online] from: https://alebank.pl/kredyty-hipoteczne-o-stalej-stopieprocentowej-w-polskich-realiach/ accessed on 15-07-2017

Principles for the Management and Supervision of Interest Rate Risk, the Basel Committee on Banking Supervision, January 2001.

Ramotowski J., 2017, Zmniejszenie ryzyka kredytowego musi mieć swoją cenę (Reducing Credit Risk Must Have a Price) [Online] from

https://www.obserwatorfinansowy.pl/tematyka/bankowosc/zmniejszenie-ryzyka-kredytowego-musimiec-swoja-cene/, accessed on 12-07-2017

Turlej J., Polityka kredytowa banku jako instrument zarządzania ryzykiem kredytowym banku (A Bank's Lending Policy as an Instrument of Managing Credit Risk), „Bank i Kredyt" (Bank and Loan), 1996, No. 7-8.

Żółtowski W., Zarządzanie ryzykiem bankowym w praktyce - w kontekście NUK (Basel II) (Banking Risk Management in Practice - in the context of Basel II), CeDeWu, Warsaw 2007. 